With this very same conviction, authors who have written on Aesthetic Issues in the journals second section go about decentering this "object" of institutional discourse by showing us that there is a wide range of aesthetics to be seen/scene at the margins. Cherokee Culture, Native American Artifacts, and the 'neighborhood' view of art are examined. These political locations constitute periphery, marginalized spaces which mainstream art education seldom entertains in its stockjournals. Rafferty's study of Vancouver graffiti artists is a paradigmatic case study of those disenfranchised artists outside the art world who legitimate themselves as artists in their revolt against arts institutionalization. In a postmodern world, the irony remains that there is no political space outside/inside the art institution. These graffiti artists have become legitimated through their very documentation. Schellin adds yet another important dimension to the artist as Outsider. He questions the representation of AIDS victims in his own poetic way, thereby heightening our consciousness as to the neglect this socio-historical issue has for art educators. Historically there has always existed an iconography of disease - how the Other's Body as unhealthy, sick, alien, is charted and mapped through the media of reproduction (newspapers, television, film, magazines). This should be the concern of all socially responsible art educators.

Men in Feminism, the third part of this journal, provides a variety of vignettes of responses by men and women who address feminism from both personal and theoretical viewpoints. Intertextually, this panel drew from Jardine and Smith's previously published book Men in Feminism, which emerged as a series of papers from a MLA conference-also presented at Washington DC. These essays provide ample evidence that Social Caucus members are fully aware of the theoretical developments in the literary field. Their responses are admirable and necessary, given, once more, the gender blindness of DBAE advocates.

Lastly, one of the most exciting sections the reader will examine, are the essays written in the area of art criticism. i am personally delighted that the four essays exemplify some of the most recent developments in art criticism, which has undergone a phenomenal change in the past several years. Tom Anderson provides us with a well balanced socially criticallook at Billboards. He has paradigmatically provided a social critique which exposes the ideological assumptions behind the advertising industry. Gaines and Paul, $i$ believe, have given us a wonderful display of how psychoanalytic art criticism is possible - Gaines through his examination of Sandra Rowe, and Paul through an entertaining playful display of word games when examining gendered images. Last, but not least, Dan Nadaner closes our journal with a thoughtful and succinct questioning whether art education can accommodate the openness of the text, the ambiguity of representation, and the multiplicity of reading which our postmodern condition has brought. This last essay, in many ways confirms and justifies the need for the existence of this Caucus.

In closing, i would like to personally thank Carolyne, Harold, Kerry, and Amy for making this issue possible through their proofing, through their typing, through their solicitation of excellent manuscripts and through their friendship. This ends my two year love-affair with this journal and $i$ wish Harold Pearse, the new editor, the best for the next two years.

\section{Creativity and Political Identification IN THE WORK OF HERBERT READ}

\section{DAVID ThISTLEWOOD}

The idea of a class conflict, in which a powerful minority subjugates the majority among other ways by depriving it of any sense of self-esteem deriving from worthwhile, original work - that is, by suppressing its creativity - was something Herbert Read acquired through his youthful involvement in the late stages of the Arts and Crafts Movement. It was a premise he was never seriously to question, as was the corresponding idea that to assert one's right to be creative was to engage in a political act. He was certain that artistic conventions were the means of suppression, and that to be truly creative required conventions to be defied, which in a sense also meant defying the social order. While the Establishment would tolerate this in individuals -indeed, encourage it for its refreshing influence upon the elites taste and artistic possessions - it could not contemplate it in the mass (in the form Read proposed in his middle age in his book Education through Art) for this would be to initiate complete social upheaval. Thus his mild-mannered arguments in favour of a properly creative education for all, and his workable proposals for implementing this, in fact made him a danger to the political standing. It was perhaps his amused realization of this which persuaded him to dramatize this aspect of his work by calling himself an anarchist.

This is the only reasonable explanation of this political identiffication of Read's, the central topic of ten of his books written after 1938, and a substantial feature of twenty-five more. For he was never a member of 'organized' Anarchism ${ }^{1}$; and what he propounded was hardly orthodox his campaigning for freedom from centralized government, for localized production, for a federated industrial economy, and above all for the preservation of regional stylistic traits in all creative work owing more to Kropotkin, and to Guild Socialism, than to Anarchism in the forms it had assumed by mid century. As Read's earliest vivid political experiences had been Guild Socialist it seems fair to consider whether he was always a Guild Socialist at heart. The purpose of such an enquiry would be to wonder whether Guild Socialism, which failed as a political force in 1922 with the collapse of the National Guilds League, lived on a philosophical force in Read's writings and survived into the present in those educational ideas of his which are still widely practised. Such an enquiry, of course, must cope with the prospect of his Guild Socialism surviving other changes of political identification too - to Marxism and to communism. And it must also consider the sources of a political persuasion positive enough to have such lasting potency.

JSTAE, No. 10, 1990 
In fact Read's inherited political instincts were Tory, for he was the son of a tenant farmer in north Yorkshire and his first perception of the world was of an utterly stable squirearchy. In 1903, however, when he was ten, his father died and his family was dispossessed of its tenancy. His mother entered domestic service, he being boarded at an orphanage school in Halifax before leaving to be a bank clerk in Leeds. The facts of industrial poverty challenged his prejudice, and by the time he entered Leeds University in 1912 to study Economics (after having matriculated at evening classes) he was ready for decisive conversion. This came about when he joined the Leeds Art Club, a society dedicated to the socialist reform of industry, politics and art, and came within the sway of his two most important mentors in political matters, Alfred Orage and Arthur Penty.

Orage had been a teacher and was an activist for the International Labour Party. Penty was an architect and member of the Northern William Morris Society. They had formed the Leeds Arts Club in $1902,{ }^{2}$ and it had gathered a membership of clerks and mechanics, teachers and benevolent employers, meeting weekly for the purpose of debate. Orage and Penty themselves had met still more frequently, with the ambitious objective of thrashing out a policy for social reform. The results of this had been that Orage was persuaded of the utter sterility which would ensue in a world of standardized possessions and lifestyles (which the extreme collectivists of his party were advocating) and that Penty began to appreciate why craftsmanship could not possibly survive in an advanced capitalist economy, with its emphasis upon the lowest acceptable standards of quality consistent with high quantity production. Their consensus - embryonic Guild Socialism ${ }^{3}$ - placed an Arts and Crafts aesthetic in the context of radical demands for wresting qualitative control from financiers. Their way forward required a regaining of contact with times when craft standards were entirely the responsibility of initiates, and of course this was labelled reactionary, not least by those socialists who considered the factory system of production, with quality control in the hands of economists, superior because it appeared to be the latest evolution of scientific progress.

Penty had moved south in 1905, at the prospect of putting his aesthetic ideals into practice, to work as a freelance architect at the first Garden City of Letchworth and at Hampstead Garden Suburb. Orage had departed for London two years later, and with Penty's help had founded The New Age, a weekly paper devoted to socialism, modern philosophy and contemporary aesthetics. There was an extensive, popular socialist awareness at this time. Texts by such as Morris and Carlyle, disseminated through worker education classes and the widespread desire for self-improvement had given rise to a concerted demand for proper housing and for civilized workplaces for the industrial poor. There was also a burgeoning middle class, inhabiting suburbia and ill appreciating its drabness and mediocrity. In these the earliest days of Labour representation in parliament the socialist press held labourer and bureaucrat within its catholic readership: the plain reader would have had grasp on a diversity of matters - social, aesthetic, economic, philosophic - as constituting socialism, and would have concurred with the demand, as an economic necessity, for the restoration of well-crafted beauty to urban life. Though Orage and Penty were no longer in Leeds when Read joined their Arts Club, their paper, and this its most dominant theme, provided the focus for weekly debates. Their influence on Read was as profound as if they had been present, resulting in two of the most consistent features of his politics, an evangelism and an insistent aesthetic. He became a regular contributor to The New Age, and the degree to which he became regarded as Orage's protegé, in particular, is demonstrated by the fact that he was asked to succeed him as its editor (this in 1922 , by which time Read was a career civil servant and nationally apolitical, which obliged him to decline). He subscribed to the paper throughout the period of Orage's and Penty's most persistent promotion of Guild Socialism as a socialist alternative to Fabianism, even contriving to receive regular copies at the front during his three years of active service in the First World War. He found their proposals so acceptable that by 1917 he had sketched out his own version of a Guild Socialist future.

He differed with the Fabians, as did Orage and Penty, on the question of materialism, opposing their concentration upon improving wages and conditions, and increasing workers' share of goods, at the expense of humanist or spiritual benefits which had been the goals of Arts and Crafts reformers. Penty found the Fabians hand-in-glove with capitalism, responsible for unaesthetic standards in industry, and compliant with wage slavery to the factory system of production. Their insistence upon improving monetary rewards, even at the expense of rewards in creative satisfaction, had led to tacit acceptance of soul-destroying (though profit-making) practices. ${ }^{5}$ Read could see no possible value in the simple transference of industry and commerce, along with an ingrained capitalism, to a government's control however beneficent. He was not entirely in accord with Penty, though, who as an architect had witnessed industrial and commercial exploitation at first hand. Read's early experiences having been rural, he felt less anxious about restoring a 'dignity of labour' to those engaged in repetitive production. In his memory even the most severely exploited had the satisfaction of working with the land, with growth and harvest and with animal husbandry, and even the meanest task had been acknowledged periodically in thanksgivings, seasonal festivities and other kinds of common celebration. His images of work were of hard toil cheerfully endured in the countryside, of industrial processes centered upon forge or smithy, and of urban employment housed in small-scale machine sheds - an imagery very similar to Kropotkin's, whose writings he admired. Penty wanted local guilds, responsible for the training of new entrants, the maintenance of highest standards of workmanship, the fixing of just prices and, most important, the preservation of genius loci as reflected in the use of local materials and the practice of techniques which satisfied specifically local requirements. Read wanted all of this and internationalism.

His was a soldier's priority to end threats of any recurrence of war He had gone to the front willingly enough and had been decorated twice for bravery; but in common with many others as the reality of war had become more and more horrifying he had begun to think it tolerable only because it would lead to an inevitable internationalism. The role of politics would be to assist in this transition, and in this sense true Guild Socialism would probably be as resistant as conservatism, tied as it would be to its exclusive localism. Read proposed a pattern of economic groupings based not upon geographic divisions but upon industries and production interests. In rural 
areas these probably would have been localized, but the world's urban centeres would have formed such an interlocked system of economic dependence as to have made any future international conflict impossible. He saw trades unions and industrial federations (such as the National Guilds League) as prototype economic groups which, with only a little more purpose, could be the regulators of an international economy; and like the Marxists he could foresee the withering of the state, though not into nonexistence but to a size commensurate with its remaining responsibilities, virtually all of which were to be cultural. ${ }^{6}$

Read's future political beliefs had roots in these convictions - another war is unthinkable; the state has no economic purpose; and the ideal form of government is one which guarantees utmost equality while preserving individual freedoms, including the right of an individual to become detached from community-interests into which he or she had been accidentally placed by birth. This is precisely what had happened to him as a result of his father's premature death; and it clearly both exhilarated and depressed him as the few' political' thoughts he expressed, while bound by the conventions of an apolitical civil service, make clear. These may be understood as an apologia for his having become divorced from the locality of his birth, and for his having found a role outside the agricultural community. His position was summarized in his critical appreciation of Julien Benda's book La Trahison des Clercs, ${ }^{7}$ in which a series of propositions were found to be so strikingly familiar that they came as self-revelations.

All real human existence is the existence of an individual, either of an individual person or of a common-interest group: it is competitive and necessarily aggressive. The 'clerc' or disinterested man or woman of learning is one who protests against a morality of aggression by proclaiming ideal values revealed in contemplation of matters abstract, universal and infinite. Civilized humanity is made possible by the coexistence and synthesis of aggressive expediency and disinterested philosophy. A world observing only a code of practical necessity would be barbarous: one which only practised a code of ideals would cease to exist. Real existence admits the gradual softening of aggression with idealism, or rather a reciprocal movement back and forth between the two polarities. Read therefore identified with the dislocated individual, leading an ostensibly unproductive life, who, however, had the special purpose of divining abstract principles for the benefit of the wider community in an age of idealism following, and counteracting a period of great international aggression. At this time in his life (under the influence of his friend T. S. Eliot, and having edited the complete works of the classicist T. E. Hulme) the goals of his aesthetic contemplation were formal precision, harmony and elegant proportion - principles which the firmly believed, when evident in literature, art and conduct, offered the world the prospect of an international medium of understanding.

This was in the 1920s. In the following decade he was an unabashed advocate of the very opposite of this, urging all creative people to cultivate the irrational and imprecise. A sudden liberation from the civil service had much to do with this, as had his discovery of a liking for surrealism ${ }^{8}$; but a significant contributory factor was his perception of the changes taking place in European politics, in particular the rise of aggressive German nationalism. He saw it as no coincidence that this nationalism attempted to eradicate abstract art, and maintained that contemporary aesthetics had to assume less easily victimized forms. He hinted at Marxian sympathies in his book Art and Society, which he wrote in 1935-6, and spelled these out most clearly in correspondence with Wyndham Lewis, in an effort to say that failure to support communism was tacit acceptance of fascism. ${ }^{9}$ It seemed obvious that communism and fascism were about to contest for domination of Europe, and that even if Britain were not directly involved individuals at least would be obliged to take sides. Though he recognized the repressive State capitalism that was the Russian reality, ${ }^{10}$ Read was prepared to countenance communism for he saw in it an essence, not present in fascism, which held promises of the abolition of bourgeois capitalism and of respect for disinterested ideals.

What prevented his becoming a communist was the movement's anti-aesthetic doctrine, in spite of all Marx had said to the contrary, and its antipathy towards all realities of art except the one it had contrived in social realism. ${ }^{11} \mathrm{He}$ was appalled to discover that contemporary art had to become active rather than contemplative, partisan rather than disinterested, and subliminal rather than superevident. It had to insinuate its ideal values as cunningly as either of the mass political movements which had opposed it. Following this line of thought the most prominent themes of Art and Society were that the greatest art of the past had belonged to communal societies, and that the modern artist, conscious of an ability to transform the world by his or her visions of a new reality, was a more consistent communist than those, so-called, who would compromise with the aesthetic conventions of a last phase of capitalism.

He hesitated before using the term 'Anarchism' to describe his preferred culture and politics because it conjured up images of cloaked figures carrying home-made bombs; but he came to believe that he had no choice. Communism, in its Russian form, had shored up the State and its bureaucracies, while Fabianism was unredeemably materialistic. Socialism (to judge by the new urban design of socialist authorities in Britain) was soulless ${ }^{12}$ while Guild Socialism, since the failure of the National Guilds League, had become nostalgic in its soulful mock-mediaevalism. In the realms of painting and sculpture guild affiliation was now associated with adherence to ancient technique, whereas during the First World War and just after it had been synonymous with pioneering experiment: Read was conscious of having himself been in the vanguard of this experimentation as a painter. ${ }^{13}$ In spite of the fact that he knew he would thus forfeit any serious consideration of his views in Britain, then, he took the concept 'Anarchism' to be the most appropriate encapsulation of his beliefs because it embraced individual freedom, self-determination, and a social framework of common-interest groupings, to which he himself added the idea of an avant-garde, agitating creativity. To the extent that he then campaigned for certain of Anarchism's socio-political ends he was thenceforth an anarchist; but because of his insistence on a very personal interpretation, featuring this essential elitist creativity, he was always an outsider.

Avant-gardes and elites are hard to reconcile with Anarchism, but to imagine a world in which the practitioners of all necessary occupations are in charge of their own affairs, democratically maintaining standards of work, establishing fair prices, and expanding the knowledge invested in 
their disciplines by means of research and experiment, is perhaps to see how they were compatible to Read. (It may be more accurate to construct an image of Guild Socialism affected by Benda's philosophy, and to imagine a society having 'internal' guilds for workaday occupations, and also 'external' guilds of experimental artists and creative thinkers and practitioners of all kinds.) In effect Read seems to have pictured a network of occupational or special interest groups, with elitism embodied in craft pride, and dedication to perfection by continuous renewal of the essential principles of each discipline, which in the realm of art of course meant commitment to avantgarde creativity.

It is significant to note that Read's very first contact with art had been with avant-garde painting. He was an utterly conventional nineteen or twenty-years-old-conservative, Christian, and with bourgeois aspirations - when he encountered works by Gauguin and Van Gogh, Klee and particularly, Kandinsky, and these so shocked and fascinated him that he was driven to an equally shocking and subversive literature for explanations. He read Bergson and Nietzsche, Hegel, Marx and Kropotkin. This experience wrought in him moral and spiritual changes which he was convinced were for the better; but the initial impetus of change had been aesthetic. And the explanations he found in philosophy were, he believed, precisely that explanations - that is, slightly weaker versions of truths perceptible in their most potent forms in the works of art themselves. This initiated his great lifelong beliefs: human concepts, of all kinds whatsoever, originate aesthetically by virtue of insight, and only subsequently percolate through philosophy and other forms of interpretation and use, eventually to become effective upon general life and conduct. Society needs individuals possessing suitably heightened sensibilities, necessary for engaging such truths or realities. The ordinary public, too, requires some inkling of this process of origination and dissemination, for such awareness and recognition will facilitate its effectiveness. In the short term this was to be provided by Read himself and others like him - intermediaries between society and its most creative artists. In the longer term, however, interpretation would be largely superfluous, because by virtue of reformed educational practices everyone would be, in some special way, an artist, and comprehension of the work of avant-gardes would be so much more direct.

As for the avant-gardes themselves, their authentic creativity would not be the property of individuals. Of course it would be effected by individuals, but by individuals who happened, Read would have said involuntarily, to be the sensitive registers of an evolving intelligence comprising the whole social body. He advocated the special creativity of certain accomplished individuals, and also the special creativity latent within everyone, because it would only be by extraordinary means that new aesthetic perceptions might be won, on behalf of society as a whole, as a vital aspect of a constant, necessary process of renewal and reinvigoration. His concept of élitism therefore held no connotations of rank or status or privilege: it simply referred to the extraordinary insight required to give shape to some value or truth newly perceived or perceived anew. And it referred to a cohort functioning as if it had no choice in the matter, for an occupation demanding constant nervous activity, and erratic fluctuation between achievement and despair, would surely have been the conscious choice of very few. It became Read's preoccupation to speak for such necessary 'outsiders', those exerting perceptive shaping influence upon the stream of ordinary events they could never join or rejoin, and to attempt to influence some co-ordination of their creative originality. It became his twin objective to raise the consciousness of ordinary people through art; and his amused realization that this was considered subversive (while encouragement of really subversive avant-garde art was not) reinforced his inclination to call himself an Anarchist.

Recantation invariably has the result of sharpening a succeeding argument's effectiveness; and what perhaps drove Read's educational pronouncements home with such force was the fact that they included recantation. In one respect he had published in haste, for at first he did not countenance the possibility that all members of the community might aspire equally to creative fulfillment. Instead he supported a distinction which had been the fundamental principle of art education in Britain, since the establishment of the South Kensington system in the mid nineteenth century, by seeming to endorse the legitimacy of one kind of provision for 'artists' and another for artisans and all the rest. it is not difficult to detect Benda's influence, and that of Freud, in suggestions that society required some external shaping guidance provided by disinterested visionaries, but that there had to be safeguards against a proliferation of visionaries too great to be supported by productive labour. Read had said as much in Art and Society, arguing that a consequent responsibility of art teachers would be to distinguish between the education of positive, creative capabilities in the few who would be initiators, and the encouragement of taste, discrimination and appreciation in the many who would be consumers. His view of the artist then was of an otherwise-neurotic who had chanced upon ways of evading this fate by expressing what would have been repressed phantasy in plastic form. And the masses either had neuroses of their own which could be cured by better housing, reformed industrial practices, and improved quality in the artefacts of everyday life, or else they possessed relatively untroubled mental personalities because they lived in the countryside or followed satisfying craftwork occupations. ${ }^{14}$ In Education through Art, however, published only six years later, everyone, that is, every child, was said to be a potential neurotic capable of being saved from this prospect if early, largely inborn, creative abilities were not repressed by conventional education. Everyone was an artist of some kind whose special abilities, even if almost insignificant, had to be encouraged as contributing to an infinite richness of collective life. ${ }^{15}$

What had prompted this change of outlook had been Read's encounter with the work of the very young. He had been advising the British Council on a collection of children's art for wartime exhibition, and in the course of this he had come across an image drawn by a five-year-old girl, which she called Snakearound the World and a Boat. ${ }^{16} \mathrm{He}$ was deeply moved, he said, upon immediately recognizing this image as a 'mandala', an ancient symbol of psychic unity, universally found in prehistoric and primitive art and in all the principal cultures of history. The child, of course, could not attach meaning to what she had done; but Read, aware for some time of what until now had been merely an interesting hypothesis of Jung's, was shocked to find phenomenal evidence of archetypal imagery. He then 
discovered an astonishing consistency in children's art of symbols Jung had associated with community stability, and he also found them brimming over in the painting and sculpture of the adult avant-garde.

The most significant of these images, to Read, was the 'mandala', which often embodied some unified shape, perhaps in the form of a flower or some other fourfold arrangement, with a distinct centre, the appearance of an unfolding, and a gathering perimeter. Especially in Eastern philosophy, though also for example in Christian iconography, these had been held to symbolize collective thought and mutual belonging. Other archetypes which gave Read shocks of recognition were the tendency to fabricate a 'dark shadow' from aspects of personality opposed to those personified in the self; and the tendency to protest against isolation, individuation and independence by creating mother-images, earth forms, and other symbols of dependence. All of these: a fixing upon abstract unities; a collation of personality traits specifically outside of the self; the celebration of maternity; an acknowledgement of belonging to the land, all of these projectionsbeyond-self, Read thought, were fundamentally Anarchistic. Objectified in the work of the avant-garde, their purpose was to guide the collective unconscious into normal patterns of aspiration and behaviour and away from conscious into normal past (mass hysteria, nationalistic pride, dumb subservience to the state) to which the unnatural mode of modern life had left people prone. This remedial function, however, would wither into uselessness if prone. This remedial function, however, would wither into uselessness if into adulthood for everyone.

When published this observation gave new meaning to the work of many thousands of art teachers. Instead of merely assisting recreational skill and consumer discrimination, their role would be to help innate creative abilities to survive in an uncongenial world, for the sake of individual wellbeing and also for the health of a collective social harmony. The potential for success was evident in Read's observation that children quite naturally give forth imagery which maintains contact with the deepest levels of social experience, and with times when social cohesion was the normal order. A corollary, which armed the art teachers and explains the normal order. A corollary, which armed the art teachers and of modern life enormous, immediate success of his botion, even war - had roots in prevail- injustice, immorality, harsh competition, in an emphasizing of intellectual development to the exclusion of everything else visited upon children from around the age of ten. Because of this the infant with inborn access to around the age of ten. Bece became a rootless ten-year-old and a centre of self interest. What passed for liberal education was nothing more than systematic repression, the elimination of which would give rise to recovery of individual, and also mutual, social health. ${ }^{17}$

Read's other twin purpose, then, encouragement of the avant-garde, assumed a temporary, but no less vital importance as he saw that it had to retain its effectiveness until such times as its forms of creativity would cease to be exceptional. This was the objective he, as founder-president, projected into the Institute of Contemporary Arts when it was established in 1947. It was the realization of longstanding ambition, for he had attempted to found an artists' guild workshop in London in 1918, a Bauhaus in Edinburgh in the 1930s, and a Museum of Modern Art in London just before the outbreak of the Second World War. None of these had materialized, but his hopes found their moment in the period of post-war reconstruction, when there seemed opportunities to fashion a civilization with fewer inherent faults than in the past.

The Institute's founding purpose was both propagandist and educational. It brought accomplished artists into contact with those who, as a result, became the next generation of accomplished artists. Ordinary members could tap current creative research at source and effect its dissemination throughout the wider community. It was not a place where art was made, but a place where the most tentative beginnings of its translation, by argument and debate, into other forms of thought and action took place. In effect it was an echo of Read's formative experience when, as a young man, the shock of unprecedented abstract images had sent him rushing to philosophy. But now the philosophical context had considerably altered. Whitehead, Jung and D'Arcy Thompson had influenced the present Zeitgeist ${ }^{18}$ and theories of collective mind and organic formation were in the air. Artists, by whose efforts the organization of society was to be incrementally changed, needed to be alive to such philosophy, the full range of aesthetic principles which had nurtured it, and its ramifications for a cross-section of human understanding. Thus the Institute embraced a comprehensive spectrum of avant-garde art, including abstraction, surrealism, and every shade or tendency between them; and it also provided a forum for advanced scientific philosophy, as well as the latest researches in sociology, anthropology and other disciplines. It was in Read's special sense an Anarchist cell, an organic community dedicated to the constant revision and reinvigoration of its essential values, to the integration of diverse interests meeting in the common sphere of art.

Two observations ought to be made in conclusion. One is that Read's political identification at this the end of his active life was clearly with Anarchism now and some Guild Socialist utopia in the discernible future. There would be a period of energetic overturning of aesthetic values (or rather turning over, in the sense of cultivation), leading to a time of great stability characterized by mutual aid and common understanding. The other observation is that his faith in an Institute of Contemporary Arts was partly justified and partly not. It stimulated a remarkable closeness of artistic and scientific communities; and it gave rise to forms of creativity process-dominant abstraction in painting and minimal constructivism in sculpture - that permeated every level of British art education and had the most widespread effectiveness of any avant-garde tendency before them. ${ }^{19}$ On the other hand, it is in the nature of avant-garde creativity to engage the unexpected, and one aspect of what was nurtured at the Institute disappointed Read greatly.

Pop art developed there when scientific influences were debased by a preoccupation with science fiction, and Jungian psychological influences corrupted by a fascination for the collective fantasies of the popular press and cinema. Read did not proceed much beyond stating the grounds upon which he would take issue - pop art was parasitic, in the sense in which advertising (its chief source of inspiration), as a servant of capitalist exploitation, was parasitic. ${ }^{20}$ By flattering something which exploited acquisitiveness and was divisive it would contribute to social disintegration, under- 
mining the natural, healthy aesthetic gains of thirty years of authentic English contemporary art. Its practitioners thought he was exhibiting fear in the face of revolutionary creative concepts, a late reluctance to come to terms with the unfamiliar. In fact it was minutely familiar to him. It was like a stranger he met whom he had always known, for its was the antithesis of all the values he had lived for. It was elitist in the way in which it patronized crude preferences and uninformed appreciation. It pretended to elevate popular taste: what it really did, however unintentionally, was to elevate the cynicism with which ordinary aesthetic sensibilities were manipulated. If it was proof of Anarchism at work it revealed a destructive aspect Read had never countenanced. His rejection of it left him clinging to a politics of constructive gradualism, in which Guild Socialism would have had its day, rather than a politics of complete disintegration as a precondition of society's reform.

\section{References}

${ }^{1}$ In the 1940 s this consisted chiefly of two organizations, the Freedom Press group, a circle of intellectuals, including close friends of Read's, who were concerned with publishing, and the Anarchist Federation of Great Britain. Read chose to distance himself from both in order not to compromise his own belief in a fundamental aspect of Anarchism that was creative. See G. Woodcock, Herbert Read: The Stream and the Source (London: Faber, 1972), ch. 7.

${ }^{2}$ See J. Carswell, Lives and Letters (London: Faber, 1978) p. 23 et seq.

${ }^{3}$ See W. Martin, The New Age under Orage (Manchester University Press, 1967), p. 208 et seq; 287 et seq.

${ }^{4}$ It has been said that Orage enhanced all contributions to Guild Socialism published in The New Age between 1912 and 1913 (see Martin, pp. 207-8). This may have been so in respect of other authors, but there is no evidence of Orage's editorial interference in Penty's surviving MSS.

${ }^{5}$ See Penty's criticism of Fabian attitudes to art and aesthetics in The New Age, vol XIV, no 13 (29 Jan. 1914), pp. 394-6.

${ }^{6} \mathrm{H}$. Read, 'The World and the Guild Idea', The Guildsman, no 5 (April 1917), p. 6; (May 1917), p. 4.

7 Op. cit., trans. R. Aldington as The Great Betrayal (London: Routledge, 1928). See Read's review of this in The Criterion, vol VIII, no XXXI (Dec. 1928), pp. 270-6.

'See D. Thistlewood, Herbert Read: Formlessness and Form (London: Routledge, 1984), chs. 3, 4

${ }^{9}$ Correspondence Read to Wyndham Lewis dated 9 Dec. 1934 (48/82/ 14.01, 14.02: Read Archive, University of Victoria BC).

${ }^{10} \mathrm{H}$. Read, Art and Society, (London: Heinemann, 1937), pp. 266-73.

"H. Read, 'Why I am a Surrealist', New English Weekly, vol 10 (4 March 1937), pp. 413-14.

${ }_{12}$ See correspondence Read to Frank Pick dated 19 Feb. 1941 (61 / 158 / 5.01-5.03 Victoria).
${ }^{13}$ While a member of the Leeds Arts Club he had painted a succession of 'Futurist' works, one of which survives (coll. Benedict Read).

${ }^{14}$ Art and Society, pp. 192-224.

${ }^{15}$ Read's change of mind obliged him to revise the offending passages in Art and Society. See the second edition of this book (London: Faber, 1945), p. 107.

${ }^{16}$ Reproduced in H. Read, Education through Art (London: Faber, 1943), fac. p. 96. The shock of this experience is recounted in $\mathrm{H}$. Read, The $\mathrm{Cult}$ of Sincerity (London: Faber, 1968). pp. 44-5. tion').

${ }^{17}$ See Education through Art, esp. ch. 7 ('The Natural Form of Educa-

${ }^{18}$ For a detailed discussion of the early ICA's philosophical context see D. Thistlewood, 'Organic Art and the Popularization of a Scientific Philosophy,' British Journal of Aesthetics, vol. 22, no 4 (Autumn 1982), pp. 311-21.

${ }^{19}$ This is surely true. In the form of 'Basic Design' they entered every level of teaching in Britain, and even became enshrined in government policy in the First Report of the National Advisory Council in Art Education (the first 'Coldstream' Report) in 1961.

${ }^{20}$ See H. Read, The Origins of Form in Art, ch. IX, esp. pp. 179-82.

This paper was read to the Nineteenth Annual Conference of the British Society of Aesthetics, September 1985 and first published in The British Journal of Aesthetics (1986), Vol. 26, No. 4. (Autumn):345-356 and republished as it appeared therein by permission of the author. 